\title{
A preliminary study of the breeding bird community of fallows of cereal steppes in southern Portugal
}

\author{
FRANCISCO MOREIRA and DOMINGOS LEITÃO
}

\section{Summary}

Counts of breeding birds in fallow land of Castro Verde region, the main steppe area of Portugal, were carried out during the spring of 1994, and the population densities of the most common species were estimated. The bird community is relatively simple, with a low species richness and diversity. Nevertheless, it includes several species with unfavourable conservation status. The most common species were Calandra Lark Melanocorypha calandra and Little Bustard Tetrax tetrax, with a mean density of, respectively, 5.6 and 2.6 males/1o ha. Other breeding species in the studied fallows include Great Bustard Otis tarda, Corn Bunting Miliaria calandra, Short-toed Lark Calandrella brachydactyla, Little Owl Athene noctua, Stone Curlew Burhinus oedicnemus, Quail Coturnix coturnix and Fan-tailed Warbler Cisticola juncidis. The results suggest that there are differences in population densities in fallows of different age and grazing intensity.

\section{Introduction}

Fallows in southern Portugal originate by the cycle of land use characteristic of extensive cereal crops. Typically, after two years during which the land is sequentially sown with wheat and oats, it is left abandoned for a variable period of generally two or three years, due to low soil productivity. This agricultural system creates a mosaic of cereal, stubble and fallow land. These fallows (called pousios) are often used as pasture for sheep. Other studies (e.g. De Juana et al. 1988, Telleria et al. 1988a, Tucker 1991) have shown that several threatened bird species use this type of landscape, for example Great Bustard Otis tarda, Montagu's Harrier Circus pygargus and Black-bellied Sandgrouse Pterocles orientalis. The present European Union (EU) subsidies given to farmers, following the Common Agricultural Policy reform, which promote land abandonment or replacement of agricultural areas by forest, and EU-funded irrigation projects, threaten the existence of these fallows and cereal steppes.

Biological data on bird communities of fallows and their relation with human (agricultural) activities are scarce. The objectives of this preliminary study were (1) to describe the breeding bird community of "pousios"; (2) to identify the conservation value of these areas; and (3) to describe possible community structure differences in fallow areas with different age and grazing intensity. 


\section{Methods}

\section{Study site}

The fieldwork was carried out in an area of about 1000 ha of fallow land in Castro Verde region (c. $37^{\circ} 43^{\prime} \mathrm{N}, 7^{\circ} 57^{\prime} \mathrm{W}$ ), in the Mesomediterranean bioclimatic stage (Rivas-Martinez 1981). Castro Verde is the most extensive area of cereal steppes in Portugal, holding most of the Portuguese population of Great Bustard and other important populations of steppe birds such as Little Bustard Tetrax tetrax, Black-bellied Sandgrouse, Calandra Lark Melanocorypha calandra, Lesser Kestrel Falco naumanni and Montagu's Harrier. The region consists of a flat mosaic of cereal, stubble and fallows of different ages, with virtually no trees. The study area is owned by Liga para a Protecção da Natureza (LPN), and was bought in the scope of a European Union project (LIFE) to protect the habitat of steppe birds.

Two areas with different characteristics were studied. One was a fallow, two years old and used for grazing by sheep (density 1.6 sheep/ha). Vegetation height was less than $25 \mathrm{~cm}$ and there was a variable proportion of bare ground visible. The other was a very old fallow (6-8 years) with a very well developed herbaceous vegetation (reaching $50 \mathrm{~cm}$ height), with virtually no bare ground visible, and ungrazed.

\section{Bird censuses}

In both areas, three strip-transects (Eberhardt 1978, Burham et al. 1980) were defined, with a belt of $100 \mathrm{~m}$ width and 850 to $1100 \mathrm{~m}$ length. Surveys were carried out three to five times in spring (between 22 April and 20 May 1994) using the following procedure: (1) two observers held a rope so that inter-observer distance was 1oom, thus defining the belt limit; (2) this rope was dragged while the transect was walked. Occasionally, a third observer walked in the middle of the transect; (3) each observer counted the number of birds seen or heard, for each species, inside the belt. Observations were registered in 10 minute intervals, to allow a posteriori comparison and interpretation of the results of both observers. It is likely that all the birds inside this belt which did not fly as the observers approached were flushed by the rope; (4) whenever possible, birds seen were classified according to sex.

Each transect was carried out during morning (o7hoo-11 hoo) or late afternoon (18h30-21hoo). Mean travel speed ( \pm SD) was $2.25 \pm 0.409 \mathrm{~km} / \mathrm{h}(n=23)$.

For data analysis, two types of variables were measured: (1) the maximum (measured in the three to five counts) number of males in each transect, inside the belt, which probably represents the best estimate of breeding male density; (2) the average number of birds seen in each transect inside the belt. Densities are expressed as males/1o ha or birds/1o ha.

\section{Results}

\section{Community structure}

Nine breeding bird species were identified in the studied "pousios", of which five (Quail Coturnix coturnix, Stone Curlew Burhinus oedicnemus, Little Owl 
Table 1. Male density ( \pm standard error), expressed as males/10 ha, in fallows of Castro Verde region

\begin{tabular}{lcc}
\hline Bird species & Mean & Range \\
\hline Calandra Lark & $5.6( \pm 0.933)$ & $4.0-10.0$ \\
Little Bustard & $2.6( \pm 0.659)$ & $0-4.7$ \\
Corn Bunting & $1.1( \pm 0.510)$ & $0-2.7$ \\
Short-toed Lark & $0.4( \pm 0.222)$ & $0-\mathbf{1 . 1}$ \\
\hline
\end{tabular}

$n=$ six transects.

Athene noctua, Fan-tailed Warbler Cisticola juncidis and Great Bustard) were too few to reliably estimate densities. The densities of breeding males, for the most common species, are shown in Table 1 . Two species are clearly abundant, Calandra Lark and Little Bustard, representing 90\% of the total bird density, and with maximum values of, respectively, 10.0 and 4.7 males/1o ha.

\section{Comparison of breeding densities in recent and old fallows}

Bird densities were higher in older "pousios", some differences being statistically significant in spite of the small sample size (Table 2). This difference was particularly significant for Calandra Lark and Little Bustard, with density values being two times higher in older fallows. For the latter species, this difference was more obvious in females (median in old fallow $=2.0$ birds/1o ha; median in recent fallow $=0.7$ birds/xo ha; Wilcoxon test, $z=-1.96, P<0.05$ ) than males (median in old fallow $=2.1$ birds/1o ha; median in recent fallow $=$ 1.7 birds/1o ha; Wilcoxon test, $z=-0.65$, NS).

\section{Discussion}

Steppe areas can be classified into two distinct categories: "natural" steppes (semi-deserts and páramos) (Telleria et al. 1988b) and cereal steppes, resulting from extensive agriculture (Martinez and Purroy 1993). The bird community of these steppes is determined mainly by bioclimatic factors and vegetation structure (Martinez and Purroy 1993). The Portuguese steppes belong to the second category and the Castro Verde region is the most extensive steppe in the country. Species richness and diversity of the breeding bird community of the studied fallows is quite low, compared with other agricultural systems occurring in the country, with only nine bird species of which two are clearly dominant, the Calandra Lark and Little Bustard. The Great Bustard is also a breeding species in the area, but its biology makes it impossible to estimate

Table 2. Bird densities (expressed as birds/10 ha) in old, non-grazed, fallows a and recent, grazed, fallows. Values are medians.

\begin{tabular}{lcc}
\hline Bird species & Recent fallow & Old fallow \\
\hline Calandra Lark & $* 4.0$ & 10.9 \\
Little Bustard & 2.5 & 4.1 \\
Corn Bunting & 0 & 1.4 \\
Short-toed Lark & 0.3 & 0.4 \\
\hline
\end{tabular}

a $n=$ three transects.

* Significant difference $(P<0.05)$ between old and recent fallows (Wilcoxon test). 
densities with the method used. The Little Owl nests in stone piles in the middle of "pousios". The remaining species probably occur in very low densities, or marginally (in ecotone areas), in the studied fallows.

Other studies (e.g. Telleria et al. 1988a, Diaz et al. 1993, Leitão 1993) of birds of cereal steppes in the Iberian Peninsula also showed a simple community structure, strongly dominated by few species (Diaz et al. 1993). Nevertheless, these dominant species are not always the same. The biggest difference of the "pousios" of Castro Verde when compared with similar areas in the Iberian Peninsula is the absence of Skylark Alauda arvensis. In fact, in this region of the country, Skylarks do not breed (Rufino 1989). Of importance in the studied "pousios" is the density of Little Bustards. Several studies (e.g. Schulz 1985, Telleria et al. 1988a, Diaz et al. 1993, Petretti 1993, Martinez 1994) suggest that Portugal has very high densities of Little Bustards. In the present work, we measured the highest density recorded in Europe so far.

The existence of long-term "pousios", with a well developed herbaceous vegetation and without grazing activity, seems to promote higher bird densities, at least for the studied species. For Little Bustard, this difference is more obvious for females, which probably benefit from a higher vegetation cover and absence of grazing for nesting and nest survival. Nevertheless, it is impossible, with the results of the present study, to determine the relative importance of fallow age and grazing intensity in the breeding density of bird species.

In spite of the simple bird community that uses "pousios" for breeding, 56\% of the species identified are included in Annex I of the birds Directive (79/409/ EEC), which clearly shows the conservation importance of this type of agricultural landscape. For most of the species present, their European population is declining or vulnerable (Tucker and Heath 1994). The Great Bustard is classified as SPEC 1 , the Little Bustard as SPEC 2 and five species as SPEC 3, and for all these species, the main threat is the loss of habitat through intensification of agriculture (Tucker and Heath 1994).

\section{Acknowledgements}

This work was carried out as part of the project "Conservation of steppe birds in Castro Verde region", funded by LIFE programme (contract 4-3200(92) 14947), Liga para a Proteç̧ão da Natureza (LPN) and Fundação Luso-Americana para o Desenvolvimento (FLAD).

\section{References}

Burham, K. P, Anderson, D. R. and Laake, J. L. (1980) Estimation of density from line transect sampling of biological populations. Wildl. Monogr. 72.

De Juana, E., Santos, A. T., Suarez, F. and Telleria, J.L. (1988) Status and conservation of steppe birds and their habitats in Spain. Pp. 113-123 in P. D. Goriup, ed., Ecology and conservation of grassland birds. Cambridge, U.K.: International Council for Bird Preservation. (Techn. Publ. No. 7).

Diaz, M, Naveso, M. A. and Rebollo, E. (1993) Respuestas de las comunidades nidificantes de aves a la intensificación agrícola en cultivos cerealistas da la Meseta Norte (Valladolid-Palencia, España). Aegypius 11 : 1-6. 
Eberhardt, L. L. (1978) Transect methods for population studies. J. Wildl. Manag. 42: 1-31. Tucker, G. M. and Heath, M. F. (1994) Birds in Europe: their conservation status. Cambridge, UK: BirdLife International (BirdLife Conservation Series No. 3).

Leitão, D. (1993) Aves dos terrenos agrícolas do estuário do Tejo: Comunidades e padrões específicos de distribuição. Relatório de estágio, Faculdade de Ciências de Lisboa, Lisboa.

Martinez, C. (1994) Habitat selection by the Little Bustard Tetrax tetrax in cultivated areas of central Spain. Biol. Conserv. 67: 125-128.

Martinez, F. J. and Purroy, F. J. (1993) Avifauna reproductora en los sistemas esteparizados ibericos. Ecologia 7: 391-401.

Petretti, F. (1993) Notes on the lek behaviour of the Little Bustard in Italy. Avocetta, 17: 19-22.

Rivas-Martinez, S. (1981) Les étages bioclimatiques de la végétation de la Péninsule Ibérique. An. Jard. Bot. Madrid 37: 251-268.

Rufino, R. (1989) Atlas das aves que nidificam em Portugal Continental. Lisboa: Centro de Estudos de Migração e Proteccão das Aves, Serviço Nacional de Párques Reservas e Conservação da Natureza.

Schulz, H. (1985) Grundlagenforschungzur biologie der Zwertrappe Tetrax tetrax. Braunschweig: Staatlichen Naturhistorischen Museum.

Telleria, J. L., Santos, T., Alvarez, G. and Sáez Royela, C. (1988a) Avifauna de los campos de cereales del interior de España. Pp. 173-319 in F. Bernis, ed., Aves de los medios urbanos y agricolas en las mesetas españolas. Madrid: Sociedad Española de Ornitoligia.

Telleria, J. L, Suárez, F. and Santos, T. (1988b) Bird communities of the Iberian shrubsteppes. Holartic Ecol. I1: 171-177.

Tucker, G. M. (1991) The status of lowland dry grassland birds in Europe. Pp. 15-36 in P. D. Goriup, L. A. Batten, and J. A. Norton, eds., The conservation of lowland dry grassland birds in Europe. Peterborough, U.K.: Joint Nature Conservancy Council.

FRANCISCO MOREIRA, DOMINGOS LEITÃO

Liga para a Proteç̧ão da Natureza, Estrada do Calhariz de Benfica, 187, P-150o Lisboa, Portugal. 